Електронне наукове фахове видання "Ефективна економіка" включено до переліку наукових фахових видань України з питань економіки (Категорія «Б», Наказ Міністерства освіти і науки України від 11.07.2019 № 975) www. economy.nayka.com.ua | № 1,2021 | 28.01.2021 p.

DOI: $10.32702 / 2307-2105-2021.1 .84$

УДК 339.1

\author{
V. Makarova \\ PhD in Economics, Associate Professor, \\ Associate Professor of the Department of Marketing and logistics, \\ Sumy National Agrarian University \\ ORCID ID: 0000-0003-1076-9246 \\ Ni Xiawei \\ Master's student, \\ Marketing and logistics Department, Sumy National Agrarian University \\ ORCID ID: 0000-0002-9345-5471
}

\title{
HUMAN RESOURCE MARKETING IS AN IMPORTANT FACTOR TO ENHANCE THE COMPETITIVENESS OF CHINESE ENTERPRISES
}

\author{
B.B. Макарова, \\ к. е. н., дочент, доиент кафедри маркетингу та логістики, \\ Сумський національний аграрний університет \\ Ні Сявей, \\ магістрант кафедри маркетингу та логістики, \\ Сумський національний аграрний університет

\section{МАРКЕТИНГ ПЕРСОНАЛУ ЯК ЧИННИК ПІДВИЩЕННЯ КОНКУРЕНТОСПРОМОЖНОСТІ ПІДПРИЕМСТВА}

On the basis of theoretical research, this paper expounds the basic connotation and necessity of human resource marketing. Then it further describes the historical development and current four new trends of human resource marketing in Chinese enterprises. The author determines that the marketing strategy of high quality human resources is an important factor to improve the competitiveness of China's high enterprises. The author introduces and analyzes in detail the main characteristics of human resource marketing activities of Chinese companies, and clarifies the interactive relationship between human resource management marketing and enterprise competitiveness from the aspects of system, culture, management, development, innovation and technology. The article points out that China's companies have been striving to build human resource management system, focusing on the establishment of human resource planning and talent pool; the construction of enterprise post qualification standard system to do a good job of human resource allocation; the establishment of scientific performance management, improvement and standardization of incentive scheme; the application of advanced technology in human resource management, Establish the network system of human resource service for enterprises. It is proved that the effectiveness of staff marketing to some extent determines the competitiveness of Chinese enterprises. Facts have proved that Chinese enterprises pay more and more attention to human resource marketing. Thus, on the example of the data of the Chinese company Haier, which specializes in the production of household appliances, the authors conducted a PEST-analysis of the company and identified the factors that shape its 
competitiveness. Among the main factors that positively affect and shape the competitive advantages of the company are significant political and economic support from the state, constantly growing market volumes, significant human resources and more. The article also provides a SWOT analysis of the company and substantiates the opportunities and threats that must be considered when developing an effective marketing strategy for the company's staff in the future.

В результаті проведеного дослідження авторами проаналізовано розвиток та сучасні тендениіі маркетингу персоналу на підприємствах Китаю. Авторами виділено три етапи розвитку маркетингу персоналу та детально проаналізовано основні особливості маркетингу персоналу китайських підприємств. Зокрема, зазначено, щуо маркетингова стратегія персоналу $\epsilon$ важливим фактором підвищення конкурентоспроможності підприємств Китаю. Досліджено основні характеристики діяльності з маркетингу персоналу китайських компаній та визначено інтерактивні взаємозв'язки між маркетингом персоналу та конкурентоспроможністю підприємств з позичій системи, культури, управління, розвитку, інновацій та технологій. В статті наголошується на тому, щзо китайські компанії прагнуть побудувати систему управління маркетингом персоналу, зосереджуючись на плануванні потреб в персоналі та залученні кваліфікованих професіоналів; побудові стандартизованої системи кваліфікачії підприємств для належної роботи маркетингу персоналу; управлінні науковими показниками, вдосконаленні та стандартизації схеми стимулювання та мотиваціі прачівників; застосуванні передових технологій в управлінні персоналом, створенні мережевої системи обслуговування персоналу для підприємств тощо. Доведено, щу ефективність маркетингу персоналу певною мірою визначає конкурентоспроможність китайських підприємств. Як наслідок изього в останні роки підприємства Китаю приділяють изьому значну увагу. Так, на прикладі даних китайської компанії Хайєр, щуо спеціалізується на виробництві побутової техніки, авторами проведено PEST-аналіз підприємства та визначені фактори, щзо формують його конкурентоспроможність. Серед основних факторів, щзо позитивно впливають та формують конкурентні переваги підприємства $є$ значна політична та економічна підтримка з боку держави, постійно зростаючі обсяги ринку, значний кадровий потенціал тощчо. В статті також проведено SWOT аналіз компанії та обгрунтовані можливості та загрози, які необхідно враховувати при розробиі ефективної маркетингової стратегії персоналу підприємства на перспективу.

Key words: human resources; human resource marketing; marketing management; competitiveness; competitive advantages.

Ключові слова: трудові ресурси; маркетинг персоналу; маркетингове управління; конкурентоспроможність; конкурентні переваги.

Problem statement. Modern enterprise human resource marketing management is complex system engineering. With the complex and changeable macro environment and competition, enterprise human resource management itself is constantly adjusted and strengthened to meet the requirements of the environment. Enterprise management itself is the continuous development in the process of interaction with the environment. In essence, human resource marketing is to realize that enterprises can provide competitive products and services by analyzing, identifying and grasping market opportunities, and meet the needs of target customers in the complex social, political and economic environment. In many aspects of the enterprise, the role of managers and human resource marketing managers is increasingly strengthened, the fundamental reason lies in the nature of managers, and enterprises are also for the society and the target market to meet its talent needs. The human resources marketing management center is the fundamental mission of how to improve the competitiveness of enterprises, that is, around the production and development of enterprises, to provide effective human resources planning and marketing positioning for enterprise development, to clarify the target talent market, to give full play to the effectiveness of human resources through market segmentation and serial marketing means, Through the integration of human resources, great competitiveness is produced.

Analysis of recent research and publications. Many scholars have noticed the important role of human resource marketing in different economic fields: Song Zhenqin [1], Gary Dessler [2], Shi en [3], Wang Jianmin. [4]. However, despite the large number of contemporary publications on this topic, the research on the relationship between human 
resource marketing and enterprise competitiveness is not enough, such as the characteristics of its important influencing factors, the degree of influence, the scope of influence and so on.

Research objective. The purpose of the article is to further expand the research scope of human resource marketing activities of Chinese enterprises, report the trend of human resource marketing market in the future, and create competitive advantages in human resource management of enterprises, so as to effectively enhance the competitiveness of the company and effectively promote the sustainable, rapid and healthy development of enterprises.

Research results. The so-called human resource marketing mainly refers to the human resource products produced and delivered by the human resource department on a monthly basis. This is one of the common enterprise activity processes of all employees in the unit. Its purpose is to make the employees understand and accept the products provided by the human resource management department. Only when employees can understand and accept these products, can they actively participate in the human resource management of enterprises, stimulates the potential of employees in the same industry, and then enhances the competitiveness of enterprises.

The active implementation of human resource marketing is determined by the characteristics of human resource management. Because the object of human resource management is all staff resources of the enterprise, compared with other functional management, it has distinctive characteristics of human-oriented management, differentiated management and team management. Due to the emphasis on people-oriented management, people are regarded as the most valuable resources in enterprises, thus establishing the dominant position of people in enterprise management. This requires enterprises to fully understand the characteristics and needs of employees in human resource management, so as to mobilize the enthusiasm of the majority of employees. Differentiation management mainly refers to the differences between different employees in personal comprehensive quality, work attitude and work performance, which requires enterprises to attach great importance to these differences in the process of human resource management and strive to achieve difference management. The implementation of team management is because the enterprise human resource management can recruit talents from the market for our own use; for those who love their own work, are highly loyal to the enterprise, have a sense of dedication and responsibility, focus on training. Changing the previous talent training mode can not only avoid the waste of human resources, but also prevent the phenomenon of one-sided pursuit of higher education, and reduce the cost of human resource management. Therefore, all kinds of scientific research units should work out a comprehensive and systematic plan to ensure the sustainable development of talents in various fields. Three historical stages of human resource marketing in Chinese enterprises (Table 1).

Table 1 - Three stages of the development of human resource marketing in Chinese Enterprises

\begin{tabular}{|c|c|l|}
\hline STAGES & PERIOD & \multicolumn{1}{c|}{ CHARACTERISTIC } \\
\hline The first stage & $\begin{array}{c}\text { The period 1978- } \\
1998\end{array}$ & $\begin{array}{l}\text { The theory of human resource management is backward. Enterprises } \\
\text { only regard employees as simple labor elements, and the behavior of } \\
\text { enterprise operators infringing on employees' interests occurs } \\
\text { frequently, and the cohesion between enterprises and employees is } \\
\text { very weak. }\end{array}$ \\
\hline The second stage & $\begin{array}{c}\text { The period 1998- } \\
2018\end{array}$ & $\begin{array}{l}\text { The internal motivation of enterprises to improve the level of human } \\
\text { resource management is insufficient. The rights of enterprises are too } \\
\text { large and the rights and interests of employees are not paid enough } \\
\text { attention to. }\end{array}$ \\
\hline The third stage & After 2018 & $\begin{array}{l}\text { The backward human resource marketing mode has been improved. } \\
\text { Such as human resource planning, recruitment management, training } \\
\text { analysis, performance evaluation management, salary design, } \\
\text { organizational management level and other aspects of technology and } \\
\text { methods }\end{array}$ \\
\hline
\end{tabular}

Source: systematized by the author

With the impact of global economic integration and cultural diversity, the traditional situation of a country's establishment of management system and mechanism will be broken.

Enterprise human resource management is responsible for the integration of different political systems, legal norms, customs and cultural backgrounds of staff cohesion. Therefore, the concept and mode of management need to be adjusted and changed; there will be a new development trend in human resource management. Four new trends of human resource marketing in Chinese enterprises (Fig. 1).

Trend one, human resource marketing management will change from closed management to open management. The traditional massive human resource management department may be weakened gradually, and the human resource management department will change from department to integration. In particular, knowledge-based economy has accelerated the technical and informatization of enterprise management. 
Trend one, human resource marketing management will change from closed management to open management

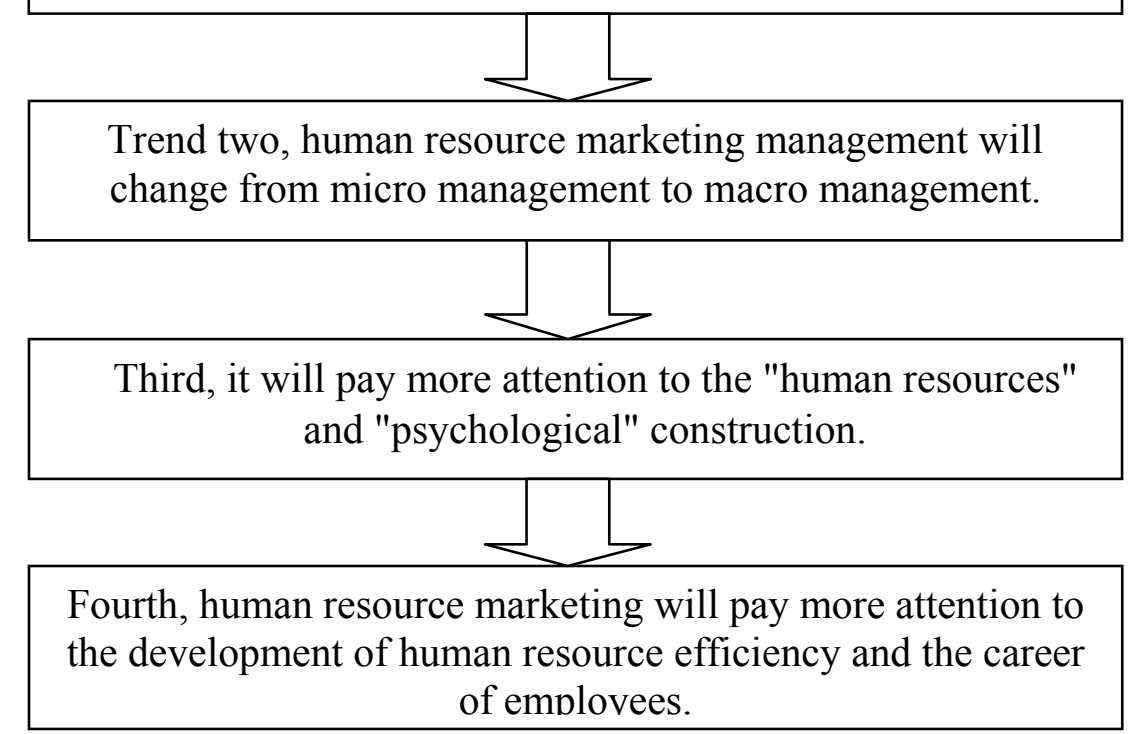

Figure 1. Four new trends of human resource marketing in Chinese Enterprises Source: systematized by the author

Human resource marketing will be carried out through public information platform. Rapid decision-making and remote management require human resource management to develop. Third, human resource marketing will pay more attention to the cultural ownership of enterprises and the construction of "psychological contract".

Second, human resource marketing management will change from micro management to macro management. The traditional "3P" management focuses on the micro marketing of human resources, and focuses on the marketing of internal human resources. With the development of human capital, modern human resource marketing management has raised human resource from the micro level of labor factors to the macro level of human capital, and evolved from tactical management to strategic management.

Third, it will pay more attention to the "human resources" and "psychological" construction. According to the theory of macro management, the organization with cohesive force and long-term high growth ability has a common ideal and mission recognized by most employees. In a sense, all the management activities of the organization are to realize the ideal and mission of the organization. Therefore, human resource marketing management tends to emphasize the construction of enterprise interest community.

The fourth trend is that human resource marketing management will pay more attention to the development of human resource efficiency and the career of employees. It will closely combine the human resource marketing management with the career of workers, so that human resource management will become a bridge between employees and enterprises, rather than simple management and element allocation. Enterprises pay attention to the development of employees and salary requirements, employees will produce centripetal force and integration force to the enterprise, which in turn provides human resource foundation and human capital pillar for the development and competitiveness of enterprises.

High quality human resource marketing strategy is an important factor to improve the competitiveness of China's high enterprises. Since the reform and opening up, with the gradual deepening of China's economic exchanges with the international community, the theory of human resource marketing in western developed countries has also begun to be introduced into China. In addition, some joint ventures and wholly-owned enterprises generally have human resource management departments. Most state-owned enterprises and private enterprises in China have gradually accepted the concept of human resource marketing management, The traditional personnel management will be transformed into human resource marketing management. According to the analysis of open data, more and more Chinese enterprises pay more and more attention to the impact of human resource marketing on the competitiveness of enterprises. At present, China's GDP has increased from 592963.23 billion yuan in 2013to 99086.511 billion yuan in 2019. According to the data analysis of China Statistical Yearbook, the impact of human resource marketing on Chinese enterprises is growing, from 15\% in 2013 to $65 \%$ in 2019 , an increase of nearly $40 \%$ (Fig. 2).

There is a positive interaction between enterprise competitiveness and human resource marketing management. "Human capital is a more important factor of production than material capital. Not only because the proportion of direct demand for knowledge and skills in production is increasing, but also in the process of the use, operation or management of material capital, knowledge and skills - living knowledge and skills condensed in the human body - are needed more and more. 

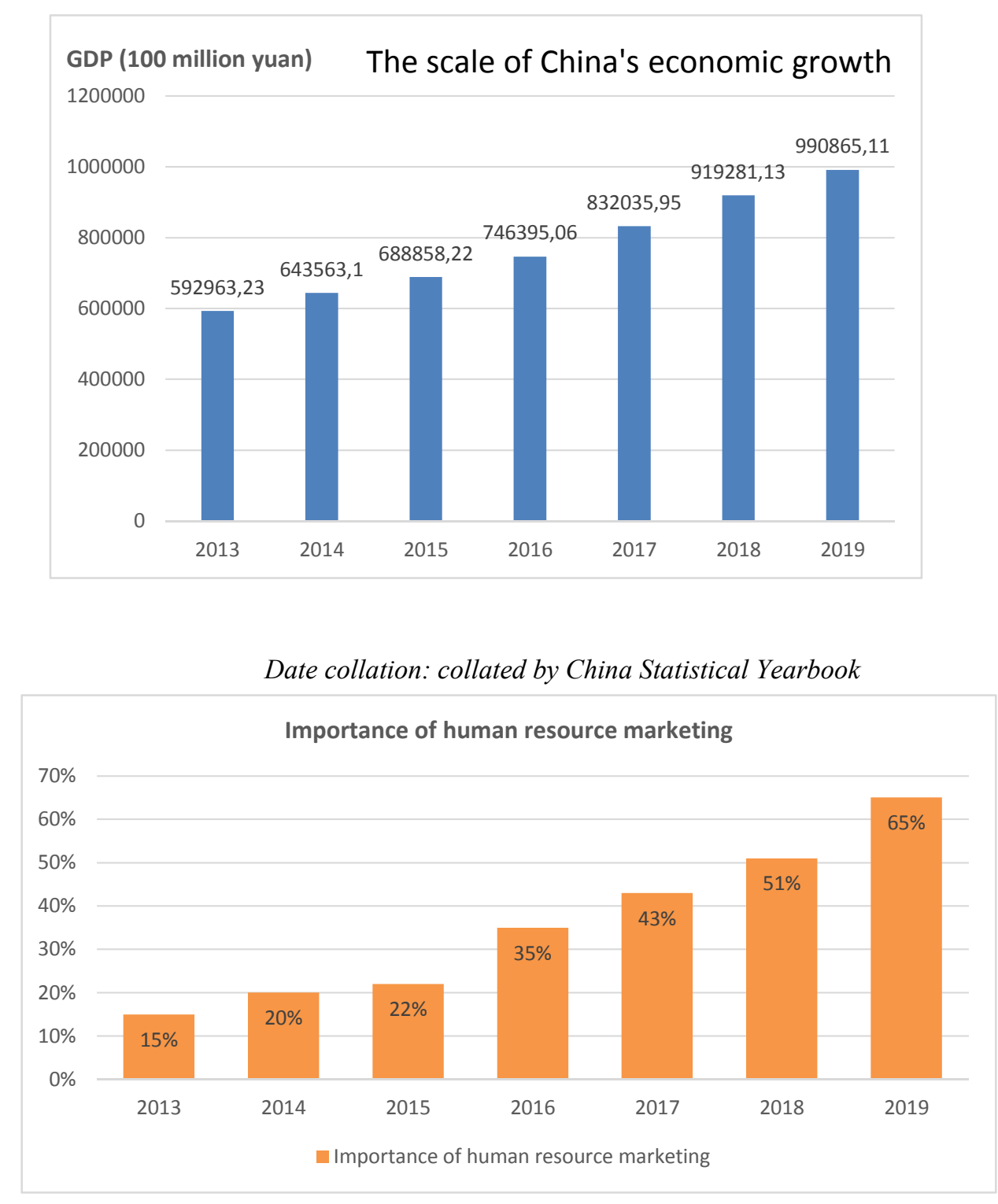

Figure 2. The development of human resource marketing in China Date collation: collated by China Statistical Yearbook

Therefore, human capital is also a kind of capital, and it is a kind of special capital. As human capital has a special contribution to the competitiveness of enterprises, how to reasonably identify the contribution of human capital and establish the contribution rate and distribution mode of human capital and other capital in the marketing management of human resources is a topic that should be paid attention to and solved to maintain and enhance the competitiveness of enterprises.

The interaction between human resources and enterprise competitiveness consists of the following aspects:

First, institutional interaction. Foreign management experts and some successful western entrepreneurs believe that the scientific marketing management of modern enterprises is based on the system and rules. Through the system integration of various production factors and resources, through the system to achieve the establishment of economic community between people and enterprises, through the system to achieve enterprise cost control and technological innovation. The system can establish the code of conduct for employees and realize the positive interaction between employees and enterprises, so as to achieve the strategic objectives of enterprises under a general principle.

Second, cultural interaction. Corporate culture is the core value of an enterprise. What kind of corporate culture an enterprise has will have what kind of competitiveness. Enterprise culture can unite people's minds, produce centripetal force and enterprise spirit, and also can relax people's mind, making enterprises become material slaves. Corporate culture, as a bridge between employees and corporate interest community, plays an important role. It can be said that corporate culture is not only the core level of human resource marketing management, but also the supporting force of enterprise competitiveness. The interaction between them is the basis of building the core competitiveness of enterprises.

Third, interaction at the management level. Enterprise management is needed to improve the competitiveness of enterprises. Human resource management is the most dynamic aspect of enterprise management. Marketing management 
is also productivity, human resource impact management is the most basic form of productivity. The efficiency of human resource marketing management is directly related to the competitiveness of enterprises.

Fourth, interaction at the development level. Whether the development of enterprises and people can be promoted simultaneously directly reflects the level and management principles of human resource marketing management. The good use of human resource marketing management can promote the development of employees while improving the competitiveness of enterprises, so that the competitiveness of enterprises and the development of employees can be achieved.

Fifth, the interaction of innovation level. Innovation is not only the life of an enterprise, but also the sustainable force of its competitiveness. Enterprises without innovation will not be competitive. Innovation is realized by people, and enterprise innovation is supported by employees. Therefore, the interaction of innovation level is also an important content of human resource marketing management. The exertion and extension of human resource marketing management efficiency can provide talent guarantee for innovation, and talent efficiency is directly related to the promotion of enterprise competitiveness.

Sixth, interaction at the technical level. The 21 st century is an information society, the cornerstone of enterprise competitiveness is technology, technology depends on human resources to achieve, human resources marketing management needs technology to provide organizational guarantee. Technology level interaction is not only the necessity of human resources, but also the key to maintain and enhance the competitiveness of enterprises.

In a modern sense, an enterprise is a place for economic production and employees' life. More importantly, it is a place for employees to realize themselves and achieve themselves. The goal of an enterprise is to unify the dual goals of enterprise growth and employee development. If an enterprise only considers the economic interests of the enterprise, regardless of the growth of its employees, it will be a short-lived enterprise, and its existence is impossible for a long time. Good human resource marketing enables enterprises to face the internal and external environment correctly and make better use of their own resources. Under the current space-time structure, it is necessary to consider how to construct the future human resources of the company to meet the needs of market competition and improve the competitiveness of enterprises.

We made PEST analysis based on Haier Group, one of the largest companies in China's electrical industry. Founded in 1984, Haier Group is a global leading provider of better life solutions. In the process of continuous entrepreneurship and innovation, Haier Group has always adhered to the development line of "human value first". Zhang Ruimin, chairman of the board of directors and CEO of Haier Group, put forward the "rendanheyi" mode. The company is mainly engaged in Omni channel sales and supply chain management of private brand electrical appliances. The company's sales network covers 19 provinces and autonomous regions, including Shanghai, Jiangsu, Zhejiang, Beijing, Tianjin, Anhui, Jiangxi, Chongqing and Guangdong. Among them, the offline channels are mainly direct chain stores, supplemented by franchise stores. They are expanded by connecting goods at the counter through stores and supermarkets, and use online channels to log in well-known shopping e-commerce platform to develop self-supporting applications, so as to provide customers with convenient and pleasant shopping experience. In 2018, the global business volume of Haier Group reached 266.1 billion Yuan, with a year-on-year growth of $10 \%$; the global total profits and taxes exceeded 33.1 billion Yuan, with a year-on-year growth of 10\%; and the ecological income reached 15.1 billion Yuan, with a year-on-year growth of 75\%. Haier has 4 listed companies, 5 Unicorn enterprises, 23 gazelle enterprises, 10 R \& D centers, 25 industrial parks, 122 manufacturing centers, 108 marketing centers and 140000 + sales network. As of June 30, 2018, there were 2352 direct chain stores (275 more than the same period in 2017) and 276 franchise stores (94 more than the same period in 2017). (Fig. 3).

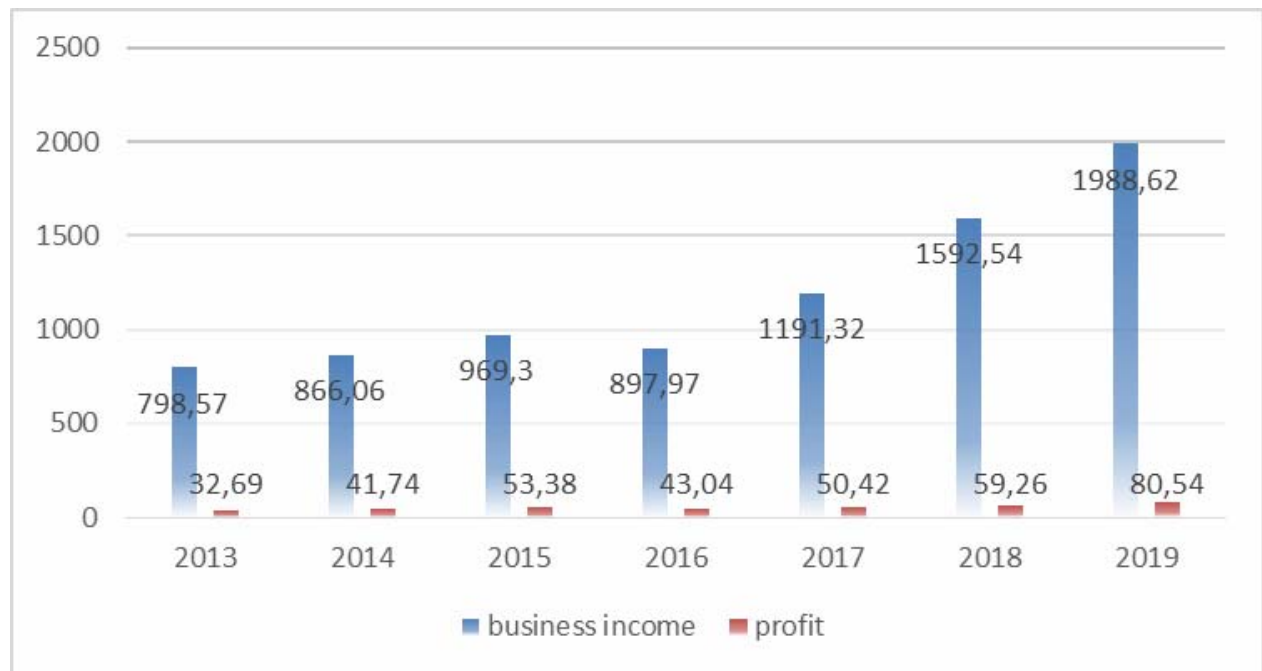

Figure 3. Haier business data statistics from 2013 to 2019

Date collation: collated by China Business Industry Research Institute database

PEST analysis refers to the in-depth analysis of various factors in the macro environment. There are mainly four types of elements: political factors, economic factors, social factors and technical factors. This method provides a 
framework for enterprises to analyze external factors and better understand and grasp the external situation. The table below shows the matrix of China Haier's electrical appliance industry from PEST analysis (Table 2).

Table 2 - PEST-analysis of China Haier Enterprise

\begin{tabular}{|c|c|}
\hline P-POLITICAL FACTORS & E-ECONOMIC FACTORS \\
\hline $\begin{array}{l}\text { 1. China provides policy support for the electrical } \\
\text { industry. } \\
\text { 2.Relevant laws are being improved. } \\
\text { 3.Strengthen the supervision of the electrical } \\
\text { industry. }\end{array}$ & $\begin{array}{l}\text { 1.Economic growth, income growth and profligacy } \\
\text { 2. The size of the home appliance market is growing. } \\
\text { 3.China's per capita consumption still has a lot of room } \\
\text { for improvement }\end{array}$ \\
\hline S-SOCIAL FACTORS & T-TECHNICAL FACTORS \\
\hline $\begin{array}{l}\text { 1. China has a large population and huge } \\
\text { consumption potential } \\
\text { 2. As the main force of consumption in household } \\
\text { appliances industry, the consumption } \\
\text { consciousness of middle-aged and elderly people } \\
\text { has been enhanced }\end{array}$ & $\begin{array}{l}\text { 1. More diversified sales channels, including offline and } \\
\text { online markets, are expanding } \\
\text { 2.It provides a more powerful backing for the } \\
\text { development of home appliance industry }\end{array}$ \\
\hline
\end{tabular}

Source: systematized by the author

SWOT analysis is an analysis of the company's internal environment, which specifically refers to strengths, weaknesses, opportunities and threats. Its value lies in the evaluation of the four aspects, reflecting the company's environmental conditions. It also considers the necessity to take measures including judging the threats of strengths, weaknesses and opportunities, and how to match the company's strategy with resources, capabilities and development opportunities, and how to learn from each other to make up for the weaknesses, To make decisions to resist external threats, we should give full play to the advantages and make up for the weakness of resources. Based on the analysis, this paper describes the company's strategic vision and business philosophy (Table3).

Through SWOT analysis, we can draw such a conclusion: first, in the face of external threats, in the fierce competition in the market competition environment, from the internal point of view, invest more time and energy to search for innovative talents for product R \& D and innovation, including product variety, product taste, product function, and strengthen innovation, so as to improve product quality, and innovative products continue to lead Haier The leading position of enterprises in the market. At present, there are various problems in Haier enterprises, which are directly related to the lack of talent resources in the industry and the low overall quality.

\section{Table 3 - SWOT-analysis of China Haier Enterprise}

\begin{tabular}{|c|c|c|}
\hline \multirow[b]{2}{*}{$\begin{array}{c}\text { The internal } \\
\text { environment } \\
(\mathrm{SW})\end{array}$} & STRENGTHS & WEAKNESSES \\
\hline & $\begin{array}{l}\text { 1. The capital scale of the company is up } \\
\text { to } 1988 \text { billion yuan, which is in the } \\
\text { forefront of the industry } \\
\text { 2. Related diversified business } \\
\text { development; } \\
\text { 3. The profits of enterprises are increasing } \\
\text { continuously } \\
\text { 4. Strong business expansion ability. }\end{array}$ & $\begin{array}{l}\text { 1. Lack of internal management foundation } \\
\text { and management ability } \\
\text { 2. The way of customer demand is } \\
\text { constantly changing } \\
\text { 3. The corporate governance structure is not } \\
\text { perfect; } \\
4 \text {. The contradiction between talent } \\
\text { allocation and company development is very } \\
\text { prominent. }\end{array}$ \\
\hline \multirow{2}{*}{$\begin{array}{c}\text { The external } \\
\text { environment } \\
\text { ( OT ) }\end{array}$} & OPPORTUNITIES & THREATS \\
\hline & $\begin{array}{l}\text { 1.Perfect human resource arrangement } \\
\text { 2. Enterprises pay attention to people's } \\
\text { values } \\
\text { 3. There are a large number of university } \\
\text { graduates with abundant talents }\end{array}$ & $\begin{array}{l}\text { 1. A large number of home appliance } \\
\text { companies have been established, and the } \\
\text { number of competitors has increased } \\
\text { 2. The enterprise risk accumulates and the } \\
\text { pressure of risk control increases; } \\
\text { 3. Government policy regulatory } \\
\text { restrictions; } \\
\text { 4. The competition for outstanding talents in } \\
\text { the industry is serious. }\end{array}$ \\
\hline
\end{tabular}

Source: systematized by the author

"People" is the key to solve the above problems, and has a direct impact on the company's resource acquisition, risk control, project service, business development, etc. the focus of Haier's industry competitiveness is strategic human resource marketing management ability, To improve the strategic human resource management ability in line with the company's strategic development, to solve the problem of excellent talent team required by the company's development, it plays an important role in R \& D of rich and diverse products that are compatible with national policies and market 
demand, actively expand enterprise resources, manage project risks and improve customer satisfaction, so as to obtain enterprise competitiveness.

Conclusion. Human resource is an essential economic resource in production activities. In the use of various economic resources, the company must give priority to human resources. Only by giving full play to the role of people can we make better use of other resources of the company and maximize the profits of the company. Therefore, through our research, from the perspective of making up for the internal disadvantages, we should strengthen the supervision of human resource marketing while expanding the sales volume and production scale of products, and form a new model of the relationship between the company and its employees -- a strategic partnership with labor contract and psychological contract as the dual link, and human centered, Communication, consensus, respect, service, innovation and cooperation have become the new principles of human resource marketing management. In addition, we should strengthen staff training and improve their sales and marketing skills. At the same time, we should enhance the sense of responsibility. Enterprises should be responsible not only to customers, but also to employees.

\section{References.}

1. Ulrich, D., Ulrich, M., Younger, J. and Brockbank, W. (2012), HR from the Outside In: Six Competencies for the Future of Human Resources, McGraw-Hill Education, USA.

2. Dessler, G. (2020), Human resource management, 15th edition, Pearson, Florida, USA.

3. Shi, En.C. (2019), Effective management of occupation. Available at https://book.douban.com/subject/1061953/ (Accessed 21 November 2020).

4. Wang, J. (2017), Preliminary study on human capital property rights. Available at: http://sky.ningbo.gov.cn/art/2017/12/21/art_11501_2285411.html (Accessed 21 November 2020).

Стаття надійшла до редакиї 09.01.2021 p. 